\title{
Ethmoid Sinus Inverted Papilloma
}

National Cancer Institute

\section{Source}

National Cancer Institute. Ethmoid Sinus Inverted Papilloma. NCI Thesaurus. Code C6843.

A benign neoplasm that arises from the ciliated respiratory mucosa that lines the ethmoid sinus. It results from the invagination and proliferation of epithelial cells in the underlying stroma. 